\title{
Tris-(1,3-diaryltriazenide) complexes of rhodium - Synthesis, structure and, spectral and electrochemical properties
}

\author{
CHHANDASI GUHAROY, ${ }^{\mathrm{a}}$ MICHAEL G B DREW ${ }^{\mathrm{b}}$ and SAMARESH BHATTACHARYA ${ }^{\mathrm{a}, *}$ \\ ${ }^{a}$ Department of Chemistry, Inorganic Chemistry Section, Jadavpur University, Kolkata 700032 \\ ${ }^{\mathrm{b}}$ Department of Chemistry, University of Reading, Whiteknights, Reading RG6 6AD, UK \\ e-mail: sbhattacharya $a$ chemistry.jdvu.ac.in
}

MS received 16 August 2008; revised 12 February 2009

\begin{abstract}
Reaction of 1,3-diaryltriazenes (abbreviated in general as HL-R, where R stands for the para-substituent in the aryl fragment and $\mathrm{H}$ stands for the dissociable hydrogen atom, $\mathrm{R}=\mathrm{OCH}_{3}, \mathrm{CH}_{3}, \mathrm{H}$, $\left.\mathrm{Cl}, \mathrm{NO}_{2}\right)$ with $\left[\mathrm{Rh}\left(\mathrm{PPh}_{3}\right)_{2}(\mathrm{CO}) \mathrm{Cl}\right]$ in ethanol in the presence of $\mathrm{NEt}_{3}$ produces a series of trisdiaryltriazenide complexes of rhodium of type $\left[\mathrm{Rh}(\mathrm{L}-\mathrm{R})_{3}\right]$, where the triazenes are coordinated to rhodium as monoanionic, bidentate N,N-donors. Structure of the $\left[\mathrm{Rh}\left(\mathrm{L}-\mathrm{OCH}_{3}\right)_{3}\right]$ complex has been determined by X-ray crystallography. The complexes are diamagnetic, and show characteristic ${ }^{1} \mathrm{H}$ NMR signals and intense MLCT transitions in the visible region. They also fluoresce in the visible region under ambient condition while excited at around $400 \mathrm{~nm}$. Cyclic voltammetry on these complexes shows a $\mathrm{Rh}(\mathrm{III})-\mathrm{Rh}$ (IV) oxidation (within $0.84-1.67 \mathrm{~V}$ vs SCE), followed by an oxidation of the coordinated triazene ligand (except the $\mathrm{R}=\mathrm{NO}_{2}$ complex). An irreversible reduction of the coordinated triazene is also observed for all the complexes below $-1.03 \mathrm{~V}$ vs SCE.
\end{abstract}

Keywords. 1,3-Diaryltriazenes; rhodium; tris complexes; N,N coordination; crystal structure; spectral and electrochemical properties.

\section{Introduction}

The chemistry of the 1,3-diaryltriazenes (1) has been receiving considerable interest in the research field because of its varied binding modes viz. monodentate, ${ }^{1}$ chelating ${ }^{2}$ and bridging. ${ }^{3}$ It is a 'short bite' ligand that normally coordinates to a metal center via dissociation of the acidic $\mathrm{N}-\mathrm{H}$ proton, as monoanionic, bidentate $\mathrm{N}, \mathrm{N}$-donor forming a four-membered chelate ring (2). ${ }^{2}$ The triazene ligands also has significant biological applications. ${ }^{4}$ In our laboratory, we have recently explored reaction of the 1,3diaryltriazenes (1) with the Wilkinson's catalyst, viz. $\left[\mathrm{Rh}\left(\mathrm{PPh}_{3}\right)_{3} \mathrm{Cl}\right]$, which brought about interesting $\mathrm{C}-\mathrm{N}$ and $\mathrm{N}-\mathrm{N}$ bond cleavage of the 1,3-diaryltriazenes leading to formation of a series $\eta^{1}$-aryl complexes. ${ }^{5}$ This observation prompted us to explore the reactivity of these triazene ligands with another rhodium(I) complex, viz. [ $\left.\mathrm{Rh}\left(\mathrm{PPh}_{3}\right)_{2}(\mathrm{CO}) \mathrm{Cl}\right]$. The primary objective of the present study was to find out whether the $\left[\mathrm{Rh}\left(\mathrm{PPh}_{3}\right)_{2}(\mathrm{CO}) \mathrm{Cl}\right]$ complex can also

*For correspondence induce similar $\mathrm{N}-\mathrm{N}$ and $\mathrm{C}-\mathrm{N}$ bond cleavage of the triazene ligands (1). Reaction of the selected 1,3diaryltriazenes (1) with $\left[\mathrm{Rh}\left(\mathrm{PPh}_{3}\right)_{2}(\mathrm{CO}) \mathrm{Cl}\right]$ did not<smiles>[R]c1ccc(/N=N/Nc2ccc([R])cc2)cc1</smiles>

1

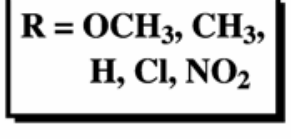

2 cause any bond cleavage of the triazene ligands, but instead afforded a family of tris-triazenide com- 
plexes of rhodium(III). The present report deals with the chemistry of these tris-triazenide complexes with special reference to their formation, structure and, spectral and electrochemical properties.

\section{Experimental}

\subsection{Materials}

Commercial rhodium trichloride was purchased from Arora Matthey, Kolkata, India. The para-substituted anilines were obtained from M/s S.D., India. All other chemicals and solvents were reagent grade commercial materials and were used as received. $\left[\mathrm{Rh}\left(\mathrm{PPh}_{3}\right)_{2}(\mathrm{CO}) \mathrm{Cl}\right]$ was prepared following a reported procedure. ${ }^{6}$ The 1,3-diaryltriazenes (1) were prepared by following a literature method. ${ }^{7}$ Purification of acetonitrile and dichloromethane, and preparation of tetrabutylammonium perchlorate (TBAP) for electrochemical work were performed as reported in the literature. ${ }^{8}$

\subsection{Synthesis of the $\left[R h(L-R)_{3}\right]$ complexes}

The $\left[\mathrm{Rh}(\mathrm{L}-\mathrm{R})_{3}\right]$ complexes were synthesized by following a general procedure. Specific details are given below for a particular complex.

[Rh( $\left.\left(\mathrm{L}-\mathrm{OCH}_{3}\right)_{3}\right]: \quad$ 1,3-Di(4'-methoxyphenyl)triazene $(112 \mathrm{mg}, 0.43 \mathrm{mmol})$ was dissolved in ethanol $(40 \mathrm{~mL})$ and triethylamine $(45 \mathrm{mg}, 0.45 \mathrm{mmol})$ was added to it. ${ }^{9}$ To the solution was then added $\left[\mathrm{Rh}\left(\mathrm{PPh}_{3}\right)_{2}(\mathrm{CO}) \mathrm{Cl}\right](100 \mathrm{mg}, 0 \cdot 14 \mathrm{mmol})$. The resulting mixture was then heated to reflux for $24 \mathrm{~h}$, whereby an orange solution was produced. Evaporation of this solution gave an orange solid, which was subjected to purification by thin layer chromatography on a silica plate. Using benzene as the eluant an orangish-yellow band separated. This band was extracted with acetonitrile. On evaporation of the acetonitrile extract complex $\left[\mathrm{Rh}\left(\mathrm{L}-\mathrm{OCH}_{3}\right)_{3}\right]$ was obtained as an orange crystalline solid. Yield: $75 \%$. Analysis: Calc for $\mathrm{C}_{42} \mathrm{H}_{42} \mathrm{~N}_{9} \mathrm{O}_{6} \mathrm{Rh}$ : C, 57.87; H, 4.82; $\mathrm{N}, 14.46 \%$. Found: C, 57.81; H, 4.80; N, $14.49 \% .{ }^{1} \mathrm{H}$ NMR: ${ }^{10} 3.75\left(6 \mathrm{OCH}_{3}\right) ; 6.74(d, 12 \mathrm{H}, J=9.0) ; 7.20$ $(d, 12 \mathrm{H}, J=9 \cdot 0)$.

[Rh( $\left(\mathrm{L}-\mathrm{CH}_{3}\right)_{3}$ ]: Yield: $74 \%$. Calc for $\mathrm{C}_{42} \mathrm{H}_{42} \mathrm{~N}_{9} \mathrm{Rh}$ : C, 65.04; H, 5.42; N, 16.26\%. Found: C, 65.01; H,
5.42; $\mathrm{N}, 16.30 \% .{ }^{1} \mathrm{H}$ NMR: $2.26\left(6 \mathrm{CH}_{3}\right) ; 6.99(d$, $12 \mathrm{H}, J=8 \cdot 6) ; 7 \cdot 16(d, 12 \mathrm{H}, J=8 \cdot 1)$.

[Rh(L-H) $)_{3}$ ]: Yield: $72 \%$. Calc for $\mathrm{C}_{36} \mathrm{H}_{30} \mathrm{~N}_{9} \mathrm{Rh}$ : C, $62.53 ; \mathrm{H}, 4.34 ; \mathrm{N}, 18.24 \%$. Found: C, 62.46; H, 4.33 ; N, $18.29 \%$. ${ }^{1} \mathrm{H}$ NMR: $7.31(d, 12 \mathrm{H}, J=6.7)$; $7 \cdot 18(t, 12 \mathrm{H}, J=8 \cdot 9) 7 \cdot 61(t, 6 \mathrm{H}, J=9 \cdot 2)$.

[Rh(L-Cl) 3 ]: Yield: 75\%. Calc. for $\mathrm{C}_{36} \mathrm{H}_{24} \mathrm{~N}_{9} \mathrm{Cl}_{6} \mathrm{Rh}$ : C, 48.11; H, 2.67; N, 14.03\%. Found: C, 48.09; H, $2 \cdot 64 ; \mathrm{N}, 14 \cdot 08 \%$. ${ }^{1} \mathrm{H}$ NMR: $7 \cdot 12-7 \cdot 21(24 \mathrm{H})^{*}$

[Rh(L-NO $\left.)_{2}\right)_{3}$ ]: Yield: $76 \%$. Calc for $\mathrm{C}_{36} \mathrm{H}_{24} \mathrm{~N}_{15} \mathrm{O}_{12}$ Rh: C, 44.96; H, 2.50; N, 21.85\%. Found: C, 44.94; $\mathrm{H}, 2.47 ; \mathrm{N}, 21.89 \%$. ${ }^{1} \mathrm{H}$ NMR: $6.62(d, 12 \mathrm{H}$, $J=8.7) ; 8.07(d, 12 \mathrm{H}, J=8.7)$.

\subsection{Physical measurements}

Microanalyses $(\mathrm{C}, \mathrm{H}, \mathrm{N})$ were done using a Heraeus Carlo Erba 1108 elemental analyzer. ${ }^{1}$ H NMR spectra in $\mathrm{CDCl}_{3}$ solutions were obtained on a Bruker Avance 300 NMR spectrometer using TMS as the internal standard. IR spectra were obtained on a Perkin-Elmer 783 spectrometer with samples prepared as $\mathrm{KBr}$ pellets. Electronic spectra were recorded on a JASCO V-570 spectrophotometer. Emission spectra were recorded in a Jobin Yvon Horiba FluoroMax 3 Luminescence Spectrometer. Electrochemical measurements were made using a $\mathrm{CH}$ Instruments model $600 \mathrm{~A}$ electrochemical analyzer. A platinum disc working electrode, a platinum wire auxiliary electrode and an aqueous saturated calomel reference electrode (SCE) were used in the cyclic voltammetry experiments. All electrochemical experiments were performed under a dinitrogen atmosphere. All electrochemical data were collected at $298 \mathrm{~K}$ and are uncorrected for junction potentials.

\subsection{X-ray crystallographic analysis}

Single crystals of $\left[\mathrm{Rh}\left(\mathrm{L}-\mathrm{OCH}_{3}\right)_{3}\right]$ were obtained by slow diffusion of acetonitrile into a dichloromethane solution of the complex. Selected crystal data and data collection parameters are given in table 1. Data were collected on a Marresearch Image Plate system using graphite monochromated $\mathrm{MoK} \alpha$ radiation. $\mathrm{X}$-ray data reduction and, structure solution and refinement were done using SHELXS-97 and SHELXL97 programs. ${ }^{11}$ The structure was solved by the direct methods. 


\section{Results and discussion}

\subsection{Synthesis and structure}

Reaction of 1,3-diaryltriazenes (1, abbreviated in general as HL-R, where $\mathrm{R}$ stands for the parasubstituent in the aryl fragment and $\mathrm{H}$ stands for the dissociable hydrogen atom, $\mathrm{R}=\mathrm{OCH}_{3}, \mathrm{CH}_{3}, \mathrm{H}, \mathrm{Cl}$, $\left.\mathrm{NO}_{2}\right)$ with $\left[\mathrm{Rh}\left(\mathrm{PPh}_{3}\right)_{2}(\mathrm{CO}) \mathrm{Cl}\right]$ in approximately $3: 1$ mole ratio proceeds smoothly in refluxing ethanol in the presence of triethylamine $\left(\mathrm{NEt}_{3}\right)$ to afford a family of orange complexes in decent yields. It is worth mentioning here that similar reaction between the 1,3-diaryltriazenes and $\left[\mathrm{Rh}\left(\mathrm{PPh}_{3}\right)_{2}(\mathrm{CO}) \mathrm{Cl}\right]$ in $1: 1$ mole ratio affords the same orange complexes but in poor $(\sim 15 \%)$ yields. Preliminary (microanalytical and spectroscopic) characterizations on these complexes indicate absence of any $\mathrm{CO}$ or $\mathrm{PPh}_{3}$ in them.

Table 1. Summary of structure determination of $[\mathrm{Rh}(\mathrm{L}-$ $\left.\left.\mathrm{OCH}_{3}\right)_{3}\right]$.

\begin{tabular}{|c|c|}
\hline Formula & $\mathrm{C}_{42} \mathrm{H}_{42} \mathrm{~N}_{9} \mathrm{O}_{6} \mathrm{Rh}$ \\
\hline Formula weight & 871.76 \\
\hline Crystal system & Trigonal \\
\hline Space group & $R \overline{3}$ \\
\hline Z & 6 \\
\hline$a(\AA)$ & $19 \cdot 5498(7)$ \\
\hline$b(\AA)$ & $19 \cdot 5498(7)$ \\
\hline$c(\AA)$ & $18.4370(7)$ \\
\hline$\alpha\left({ }^{\circ}\right)$ & 90 \\
\hline$\beta\left(^{\circ}\right)$ & 90 \\
\hline$\gamma\left({ }^{\circ}\right)$ & 120 \\
\hline$v\left(\AA^{3}\right)$ & $6102 \cdot 5(4)$ \\
\hline$\mu\left(\mathrm{mm}^{-1}\right)$ & 0.479 \\
\hline Crystal size $\left(\mathrm{mm}^{3}\right)$ & $0.03 \times 0.04 \times 0.22$ \\
\hline$T(\mathrm{~K})$ & 150 \\
\hline$D_{\text {calc }}\left(\mathrm{g} / \mathrm{cm}^{3}\right)$ & 1.423 \\
\hline$\lambda(\AA)$ & 0.71073 \\
\hline No. of reflections measured & 13929 \\
\hline No. of unique reflections & 3943 \\
\hline$R_{1}$ indices $^{\mathrm{a}, \mathrm{b}}(F>4 \sigma(F))$ & 0.0862 \\
\hline$w R_{2}$ & $0 \cdot 2307$ \\
\hline $\mathrm{GOF}^{\mathrm{c}}$ & 1.05 \\
\hline
\end{tabular}

Table 2. Selected bond lengths $(\AA)$ and angles $\left(^{\circ}\right)$ for $\left[\mathrm{Rh}\left(\mathrm{L}-\mathrm{OCH}_{3}\right)_{3}\right]$.

\begin{tabular}{llll}
\hline Bond lengths $(\AA)$ & & & \\
Rh1-N1 & $2 \cdot 033(4)$ & C11-N1 & $1 \cdot 392(6)$ \\
Rh1-N3 & $2 \cdot 026(6)$ & N1-N2 & $1 \cdot 317(7)$ \\
& & N2-N3 & $1 \cdot 306(8)$ \\
& & N3-C31 & $1 \cdot 398(9)$ \\
Bond angles $\left({ }^{\circ}\right)$ & & & \\
N1-Rh1-N3b & $162 \cdot 6(2)$ & N1-Rh1-N3 & $61 \cdot 0(19)$ \\
\hline
\end{tabular}

For an unambiguous characterization of these complexes, with regard to composition, stereochemistry and binding mode of the triazene ligands, structure of a representative member of the family, viz. the complex obtained from the reaction with $\mathrm{HL}-\mathrm{OCH}_{3}$, has been determined by X-ray crystallography. The structure is shown in figure 1 and selected bond parameters are listed in table 2. The structure shows that in this complex three triazene ligands are coordinated to rhodium as monoanionic bidentate $\mathrm{N}, \mathrm{N}-$ donors, via dissociation of the $\mathrm{N}-\mathrm{H}$ proton, forming four-membered chelate rings (2). In this complex rhodium is therefore sitting in a $\mathrm{N}_{6}$ coordination en-

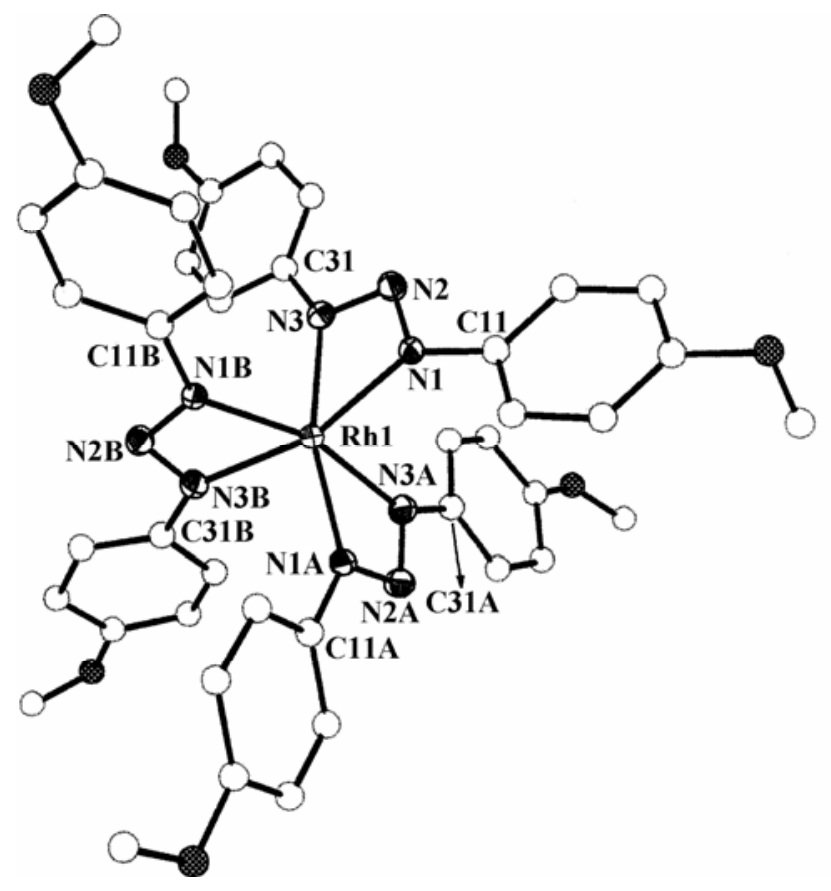

Figure 1. View of the $\left[\mathrm{Rh}\left(\mathrm{L}-\mathrm{OCH}_{3}\right)_{3}\right]$ complex.

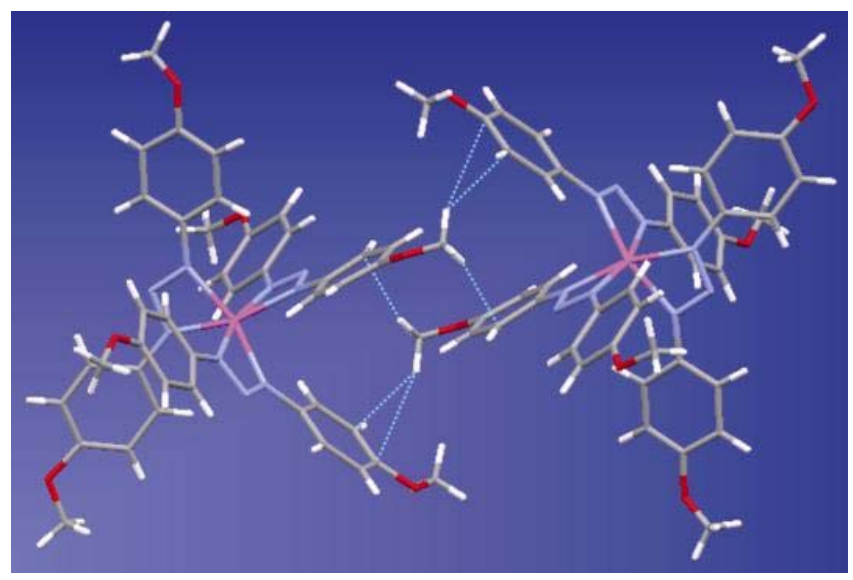

Figure 2. $\mathrm{C}-\mathrm{H}---\pi$ interactions in the lattice of the $\left[\mathrm{Rh}\left(\mathrm{L}-\mathrm{OCH}_{3}\right)_{3}\right]$ complex. 
vironment, which is distorted significantly from ideal octahedral geometry, as reflected in the bond parameters around rhodium. This distortion is particularly attributable to the strain imposed by formation of the four-membered chelate rings with relatively small bite angles $\left(61.0(19)^{\circ}\right)$ by the triazene ligands. The $\mathrm{Rh}-\mathrm{N}$ distances and the bond lengths within the coordinated ligands are quite normal. ${ }^{2}$ This orange complex and the other four complexes of this family are therefore formulated in general as $\left[\mathrm{Rh}(\mathrm{L}-\mathrm{R})_{3}\right]$. It may be mentioned here that synthesis of such tris(1,3-diaryltriazenide) complexes of rhodium has precedence in the literature. ${ }^{2 f, 12}$

The absence of any solvent of crystallization in the lattice of $\left[\mathrm{Rh}\left(\mathrm{L}-\mathrm{OCH}_{3}\right)_{3}\right]$ indicates possible existence of non-covalent interaction(s) between the individual complex molecules. An examination of the packing pattern in the lattice reveals that $\mathrm{C}-\mathrm{H}---\pi$ interactions of two types, involving methoxy $\mathrm{C}-\mathrm{H}$ 's and $\pi$-clouds over the aryl rings, are active in the lattice (figure 2). Each individual complex molecule is thus linked with its neighbouring molecules through such $\mathrm{C}-\mathrm{H}---\pi$ interactions, and these extended intermolecular interactions seem to be responsible for holding the crystal together. It may be relevant to note here that such non-covalent interactions are of significant importance in crystal engineering and biology. ${ }^{13}$ As all the $\left[\mathrm{Rh}(\mathrm{L}-\mathrm{R})_{3}\right]$ complexes have been synthesized similarly and they show similar properties (vide infra), the other four $\left[\mathrm{Rh}(\mathrm{L}-\mathrm{R})_{3}\right]\left(\mathrm{R} \neq \mathrm{OCH}_{3}\right)$ complexes are assumed to have similar structures as $\left[\mathrm{Rh}\left(\mathrm{L}-\mathrm{OCH}_{3}\right)_{3}\right]$.

Formation of the tris-triazenide complexes of rhodium(III) starting from a mixed ligand complex of rhodium(I) via displacement of all the coordinated ligands, viz. two triphenylphosphines, a carbonyl and a chloride, was quite intriguing. Though the exact sequences behind formation of these $\left[\mathrm{Rh}(\mathrm{L}-\mathrm{R})_{3}\right]$ complexes are not completely clear, the speculated steps shown in scheme 1 seem probable. In the initial step, a 1,3-diaryltriazene reacts with the metal center in $\left[\mathrm{Rh}\left(\mathrm{PPh}_{3}\right)_{2}(\mathrm{CO}) \mathrm{Cl}\right]$, whereby oxidative insertion of rhodium into the $\mathrm{N}-\mathrm{H}$ bond takes place with simultaneous and usual dissociation of a $\mathrm{PPh}_{3}$ from the metal center, affording a mono-hydride species. The $\mathrm{Rh}-\mathrm{Cl}$ bond is also believed to get converted into a $\mathrm{Rh}-\mathrm{H}$ bond under the prevailing reaction condition generating a di-hydride intermediate. Such conversion of $\mathrm{M}-\mathrm{Cl}$ into $\mathrm{M}-\mathrm{H}$ in alcoholic medium in the presence of a base is well documented in the literature. ${ }^{14}$ This di-hydride intermediate then reacts with a second triazene ligand, which links itself to the metal center as a $\mathrm{N}, \mathrm{N}$-donor, probably via initial acid-base reaction between the $\mathrm{N}-\mathrm{H}$ proton of the triazene ligand and the metalbound hydride, followed by displacement of another $\mathrm{PPh}_{3}$, probably favoured by the chelate effect. Chelation of the third 1,3-diaryltriazene takes place similarly, first via elimination of $\mathrm{H}_{2}$ followed by displacement of $\mathrm{CO}$, to yield the $\left[\mathrm{Rh}(\mathrm{L}-\mathrm{R})_{3}\right]$ complexes. Elimination of molecular hydrogen or carbon monoxide during the course of the synthetic reaction could not be experimentally verified. In an attempt to isolate the mono-hydride species formed initially, reaction of the 1,3-diaryltriazenes was carried out with equimolar quantity of $\left[\mathrm{Rh}\left(\mathrm{PPh}_{3}\right)_{2}(\mathrm{CO}) \mathrm{Cl}\right]$, which (as stated earlier) also afforded the same $\left[\mathrm{Rh}(\mathrm{L}-\mathrm{R})_{3}\right]$ complexes in much lower yields.

\section{$3.2{ }^{1}$ H NMR spectra}

All the $\left[\mathrm{Rh}(\mathrm{L}-\mathrm{R})_{3}\right]$ complexes are diamagnetic, which corresponds to the trivalent state of rhodium (lowspin $d^{6}, S=0$ ) in them. ${ }^{1} \mathrm{H}$ NMR spectra of these complexes have been recorded in $\mathrm{CDCl}_{3}$ solution. The spectra are in well agreement with the highly symmetric nature of these complexes. The characteristic signals for the methoxy and methyl groups in the $\left[\mathrm{Rh}\left(\mathrm{L}-\mathrm{OCH}_{3}\right)_{3}\right]$ and $\left[\mathrm{Rh}\left(\mathrm{L}-\mathrm{CH}_{3}\right)_{3}\right]$ complexes appear at 3.75 and $2.26 \mathrm{ppm}$ respectively. In the aromatic region, only two distinct doublets could be observed for the three $\left[\mathrm{Rh}(\mathrm{L}-\mathrm{R})_{3}\right]$ complexes with $\mathrm{R}=\mathrm{OCH}_{3}, \mathrm{CH}_{3}$ and $\mathrm{NO}_{2}, \neq \mathrm{H}$. The more deshielded doublet is assigned to the ortho (with respect to the triazene function) protons and the less deshielded one to the meta ones. In the $\left[\mathrm{Rh}(\mathrm{L}-\mathrm{Cl})_{3}\right]$ complex these doublets could not be distinctly recognized due to overlap problem. In $\left[\mathrm{Rh}(\mathrm{L}-\mathrm{H})_{3}\right]$ one doublet at $7.31 \mathrm{ppm}$ (due to the ortho protons) and two triplets at $7.18 \mathrm{ppm}$ (due to the meta protons) and at $7.61 \mathrm{ppm}$ (due to the para protons) are observed as expected. The ${ }^{1} \mathrm{H}$ NMR spectral data of the $[\mathrm{Rh}(\mathrm{L}-$ $\mathrm{R})_{3}$ ] complexes are therefore consistent with their composition and stereochemistry.

\subsection{IR spectra}

Infrared spectra of the $\left[\mathrm{Rh}(\mathrm{L}-\mathrm{R})_{3}\right]$ complexes show many bands of varying intensities within 4000$400 \mathrm{~cm}^{-1}$. Assignment of each individual band to a specific vibration has not been attempted. However, the $\mathrm{N}-\mathrm{H}$ stretch observed in the spectra of the uncoordinated triazene ligands around $3205 \mathrm{~cm}^{-1}$ is 


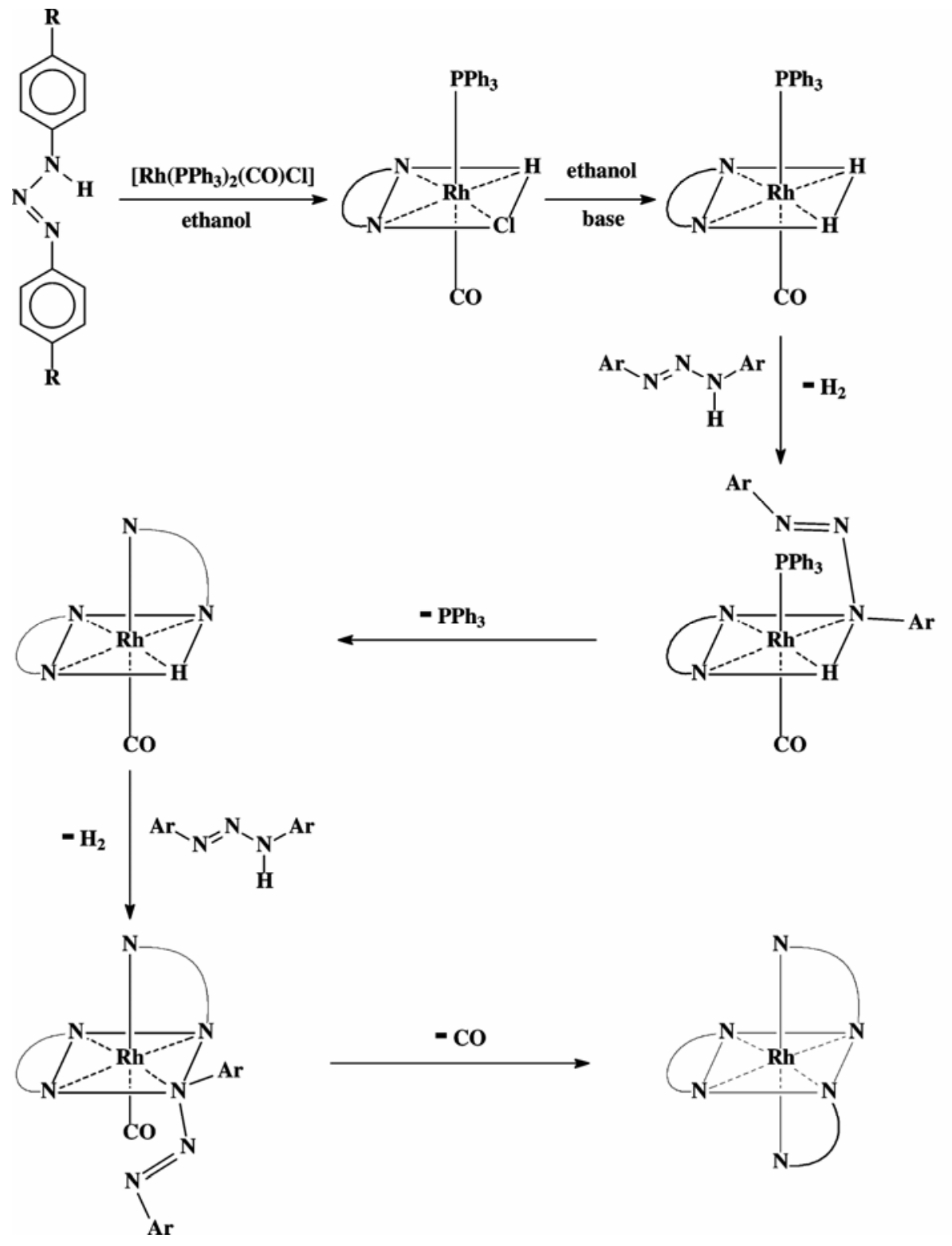

Scheme 1.

found to be absent in the spectra of the complexes, supporting loss of this $\mathrm{N}-\mathrm{H}$ proton upon complexation. The $v(\mathrm{NN})$ bands arising from the triazene fragment appear around 1242 and $1500 \mathrm{~cm}^{-1}$ for all the complexes. ${ }^{2 f}$

\subsection{Electronic absorption spectra}

Electronic spectra of all the complexes have been recorded in dichloromethane solution. Spectral data are presented in table 3. Spectrum of a selected complex is shown in figure 3 . The complexes show several intense absorptions in the visible and ultraviolet region. ${ }^{15}$ The absorptions in the ultraviolet re- gion are believed to be due to transitions within the ligand orbitals. To have an insight into the nature of absorptions in the visible region, semi-empirical EHMO calculations by the CACAO package programs ${ }^{16}$ have been performed on computer-generated models of all the complexes. The results are found to be qualitatively similar for all the complexes. ${ }^{17}$ Compositions of some selected molecular orbitals are given in table 4 and partial MO diagram of a representative complex is shown in figure 4 . The calculations show that in the $\left[\mathrm{Rh}(\mathrm{L}-\mathrm{R})_{3}\right]$ complexes the highest occupied molecular orbital (HOMO) has major $(>50 \%)$ contribution from the metal $d$ orbitals. The next two filled molecular orbitals 
Table 3. Electronic spectral and cyclic voltammetric data of the $\left[R h(L-R)_{3}\right]$ complexes.

\begin{tabular}{lccc}
\hline & & \multicolumn{2}{c}{ Cyclic voltammetric data ${ }^{\mathrm{b}} \mathrm{E}, \mathrm{V}$ vs SCE } \\
\cline { 3 - 4 } Compounds & Electronic spectral data ${ }^{\mathrm{a}} \lambda_{\max }(\mathrm{nm})\left(\varepsilon / \mathrm{M}^{-1} \mathrm{~cm}^{-1}\right)$ & Oxidative responses & Reductive response \\
\hline$\left.\left[\mathrm{Rh}(\mathrm{L}-\mathrm{OCH})_{3}\right)_{3}\right]$ & $252(9400), 316^{\mathrm{c}}(4400), 418(6800)$ & $0 \cdot 84^{\mathrm{d}}, 1 \cdot 01^{\mathrm{d}}$ & $-1 \cdot 03^{\mathrm{e}}$ \\
$\left.\left[\mathrm{Rh}(\mathrm{L}-\mathrm{CH})_{3}\right)_{3}\right]$ & $252(8600), 306^{\mathrm{c}}(3700), 414(5800)$ & $1 \cdot 08^{\mathrm{d}}, 1 \cdot 33^{\mathrm{d}}$ & $-1 \cdot 10^{\mathrm{e}}$ \\
{$\left[\mathrm{Rh}(\mathrm{L}-\mathrm{H})_{3}\right]$} & $250(10100), 300^{\mathrm{c}}(2500), 406(6340)$ & $1 \cdot 29^{\mathrm{d}}, 1 \cdot 51^{\mathrm{d}}$ & $-1 \cdot 08^{\mathrm{e}}$ \\
{$\left[\mathrm{Rh}(\mathrm{L}-\mathrm{Cl})_{3}\right]$} & $250^{\mathrm{c}}(12100), 306^{\mathrm{c}}(4200), 412(7100)$ & $1 \cdot 31^{\mathrm{d}}, 1 \cdot 67^{\mathrm{d}}$ & $-1 \cdot 09^{\mathrm{e}}$ \\
{$\left[\mathrm{Rh}\left(\mathrm{L}-\mathrm{NO}_{2}\right)_{3}\right]$} & $230(3700), 350(8200)$ & $1 \cdot 46^{\mathrm{d}}$ & $-1 \cdot 13^{\mathrm{e}}$ \\
\hline
\end{tabular}

${ }^{\mathrm{a}}$ In dichloromethane solution

${ }^{\mathrm{b}}$ Solvent: 1 : 9 dichloromethane-acetonitrile; supporting electrolyte: TBAP; scan rate: $50 \mathrm{mVs}^{-1}$

${ }^{\mathrm{c}}$ Shoulder; ${ }^{\mathrm{d}} E_{\mathrm{pa}}$ value, where $E_{\mathrm{pa}}$ is the anodic peak potential; ${ }^{\mathrm{e}} E_{\mathrm{pc}}$ value, where $E_{\mathrm{pc}}$ is the cathodic peak potential

Table 4. Composition of molecular orbitals.

\begin{tabular}{|c|c|c|c|c|c|c|c|}
\hline \multirow[b]{2}{*}{ Compounds } & \multirow{2}{*}{$\begin{array}{l}\text { Contributing } \\
\text { fragments }\end{array}$} & \multicolumn{5}{|c|}{$\%$ Contribution of fragments to } & \multirow[b]{2}{*}{$\mathrm{LUMO}+2$} \\
\hline & & HOMO & HOMO-1 & HOMO-2 & LUMO & LUMO + 1 & \\
\hline \multirow{2}{*}[\mathrm{Rh}(\mathrm{L}-\mathrm{OCH}_{3})_{3}]{} & $\mathrm{Rh}$ & 51 & 40 & 32 & - & 17 & 37 \\
\hline & Triazene & 46 & 56 & 67 & $97(\mathrm{~N}-\mathrm{N}-\mathrm{N}=48)$ & 78 & 59 \\
\hline \multirow{2}{*}[\mathrm{Rh}(\mathrm{L}-\mathrm{CH}_{3})_{3}]{} & $\mathrm{Rh}$ & 50 & 40 & 33 & - & 18 & 33 \\
\hline & Triazene & 47 & 57 & 64 & $97(\mathrm{~N}-\mathrm{N}-\mathrm{N}=47)$ & 78 & 59 \\
\hline \multirow{2}{*}[\mathrm{Rh}(\mathrm{L}-\mathrm{H})_{3}]{} & $\mathrm{Rh}$ & 50 & 38 & 34 & - & 17 & 21 \\
\hline & Triazene & 49 & 53 & 60 & $95(\mathrm{~N}-\mathrm{N}-\mathrm{N}=40)$ & 76 & 73 \\
\hline \multirow[t]{2}{*}[\mathrm{Rh}(\mathrm{L}-\mathrm{Cl})_{3}]{} & $\mathrm{Rh}$ & 44 & 30 & 15 & - & 17 & 20 \\
\hline & Triazene & 52 & 63 & 82 & $97(\mathrm{~N}-\mathrm{N}-\mathrm{N}=46)$ & 79 & 77 \\
\hline \multirow[t]{2}{*}[\mathrm{Rh}(\mathrm{L}-\mathrm{NO}_{2})_{3}]{} & $\mathrm{Rh}$ & 52 & 43 & 37 & - & 5 & 2 \\
\hline & Triazene & 39 & 49 & 56 & $\begin{array}{c}98(\mathrm{~N}-\mathrm{N}-\mathrm{N}=32) \\
\left(\mathrm{NO}_{2}=18\right)\end{array}$ & 96 & 94 \\
\hline
\end{tabular}

Table 5. Emission spectral data for the $\left[\mathrm{Rh}(\mathrm{L}-\mathrm{R})_{3}\right]$ complexes.

\begin{tabular}{|c|c|c|c|}
\hline \multirow[b]{3}{*}{ Compound } & \multicolumn{3}{|c|}{ Emission data } \\
\hline & \multicolumn{2}{|c|}{$\lambda_{\max }(\mathrm{nm})$} & \multirow[b]{2}{*}{ Quantum yield $(\phi)$} \\
\hline & Excitation & Emission & \\
\hline$\left[\mathrm{Rh}\left(\mathrm{L}-\mathrm{OCH}_{3}\right)_{3}\right]$ & 418 & 466 & 0.007 \\
\hline$\left[\mathrm{Rh}\left(\mathrm{L}-\mathrm{CH}_{3}\right)_{3}\right]$ & 414 & 461 & $0 \cdot 016$ \\
\hline$\left[\mathrm{Rh}(\mathrm{L}-\mathrm{H})_{3}\right]$ & 406 & 454 & $0 \cdot 012$ \\
\hline$\left[\mathrm{Rh}(\mathrm{L}-\mathrm{Cl})_{3}\right]$ & 412 & 453 & 0.007 \\
\hline$\left[\mathrm{Rh}\left(\mathrm{L}-\mathrm{NO}_{2}\right)_{3}\right]$ & 350 & 390 & 0.050 \\
\hline
\end{tabular}

(HOMO-1 and HOMO-2) also have significant contribution from rhodium. The lowest unoccupied molecular orbital (LUMO) is localized almost entirely on one 1,3-diaryltriazenide ligand and is concentrated mostly $(>40 \%)$ on the triazene fragment. ${ }^{17}$ The next two vacant molecular orbitals (LUMO + 1 and LUMO + 2) are localized on the two other coordinated 1,3-diaryltriazene ligands. Hence the lowest energy absorption near $400 \mathrm{~nm}$ may be assigned to an electronic transition from the filled rhodium orbital (HOMO) to the vacant $\pi^{*}$-orbital (LUMO) localized on the triazene fragment of a coordinated 1,3-diaryltriazene ligand. The relatively high intensities of the charge-transfer transitions in the visible region tempted us to explore the luminescence properties of these complexes. In ethanol solution at ambient temperature $(298 \mathrm{~K})$ all the complexes have been found to display emission in the visible region 

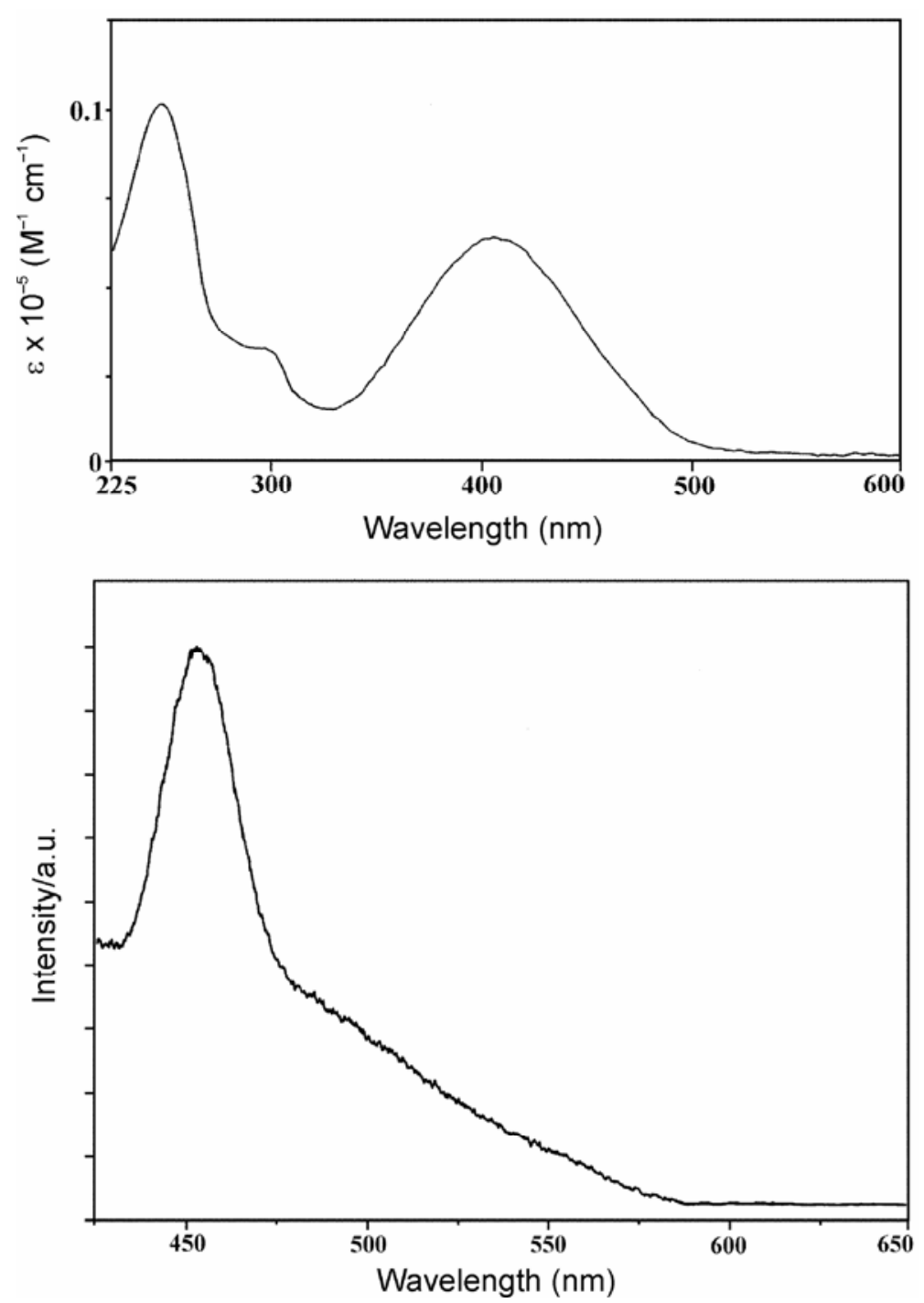

Figure 3. Absorption (top) emission (bottom) spectra of the $\left[\mathrm{Rh}(\mathrm{L}-\mathrm{H})_{3}\right]$ complex.

using an excitation wavelength of $\sim 400 \mathrm{~nm}^{18}$ (figure 3). Quantum yields $(\phi)$ of these emissions have been evaluated (table 5) with reference to $\left[\mathrm{Ru}(\mathrm{bpy})_{3}\right] \mathrm{Cl}_{2}$ $(\phi=0.028$ at $298 \mathrm{~K}),{ }^{19}$ which shows that these complexes are fairly good emitters under ambient conditions.

\subsection{Electrochemical properties}

Electrochemical properties of the $\left[\mathrm{Rh}(\mathrm{L}-\mathrm{R})_{3}\right]$ complexes have been studied by cyclic voltammetry in $1: 9$ dichloromethane-acetonitrile solution $(0.1 \mathrm{M}$ TBAP) ${ }^{20}$ Voltammetric data are presented in table 3 and a representative voltammogram is deposited as figure 5. The complexes show two irreversible oxidative responses on the positive side of $\mathrm{SCE}^{21}$ and a reductive response on the negative side. In view of the composition of the HOMO (vide infra) the first oxidation is assigned to $\mathrm{Rh}(\mathrm{III})-\mathrm{Rh}(\mathrm{IV})$ oxidation. The second oxidation is tentatively attributed to the oxidation of a coordinated triazene ligand. The reductive response is irreversible and, based on the composition of the LUMO, is assigned to reduction of the triazene fragment in the coordinated ligand. It may be mentioned here that, though the Rh(III)$\mathrm{Rh}(\mathrm{IV})$ oxidation potential increases with increasing $\sigma$ value of substituent $\mathrm{R}$ in the $\left[\mathrm{Rh}(\mathrm{L}-\mathrm{R})_{3}\right]$ complexes, no linear correlation has been found to exist between oxidation potentials and $6 \sigma$.

\section{Conclusions}

The present study shows that the 1,3-diaryltriazenes $(\mathrm{HL}-\mathrm{R}, 1)$ can readily react with $\left[\mathrm{Rh}\left(\mathrm{PPh}_{3}\right)_{2}(\mathrm{CO}) \mathrm{Cl}\right]$, 

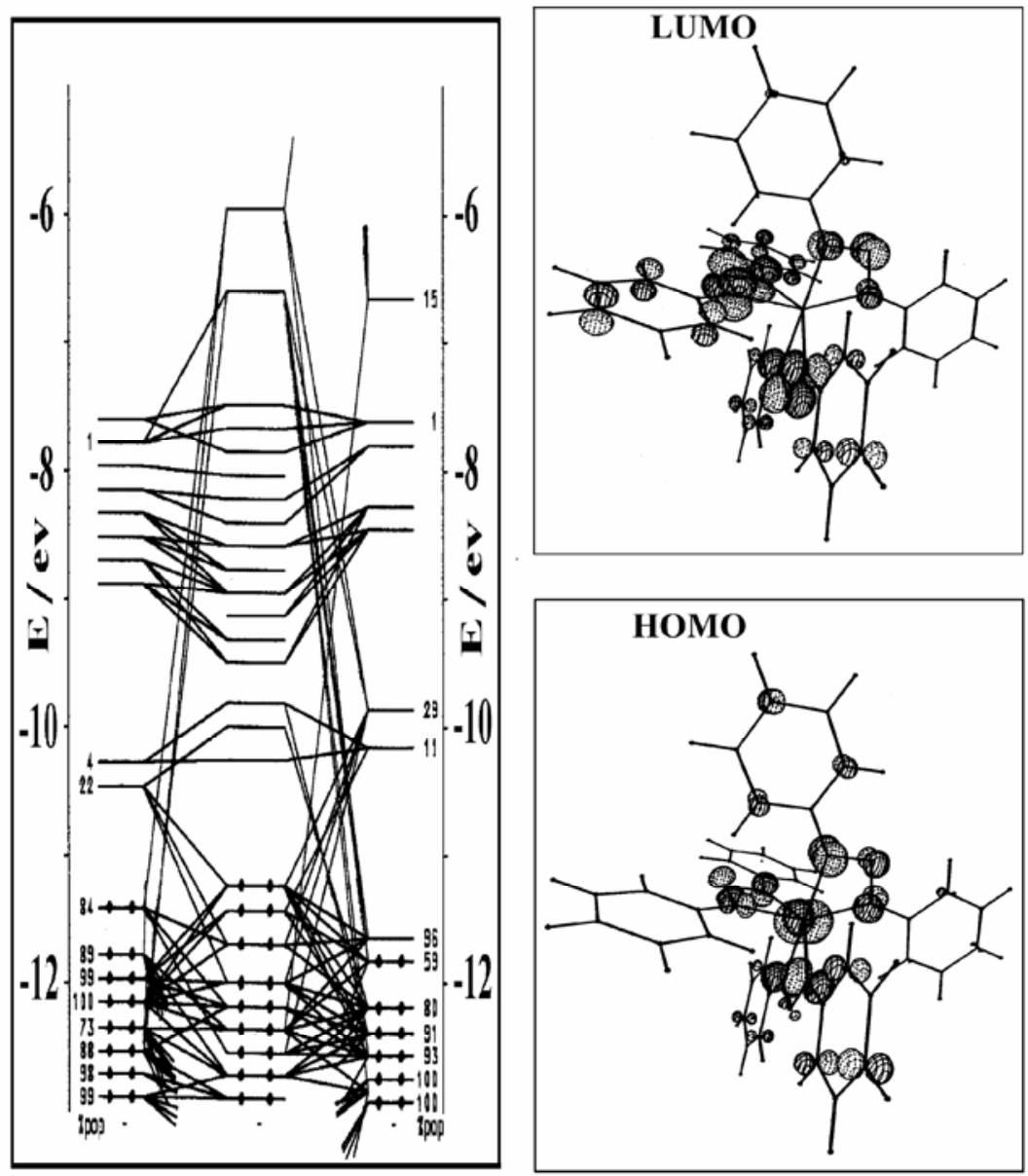

Figure 4. Partial molecular orbital diagram of the $\left[\mathrm{Rh}(\mathrm{L}-\mathrm{H})_{3}\right]$ complex.

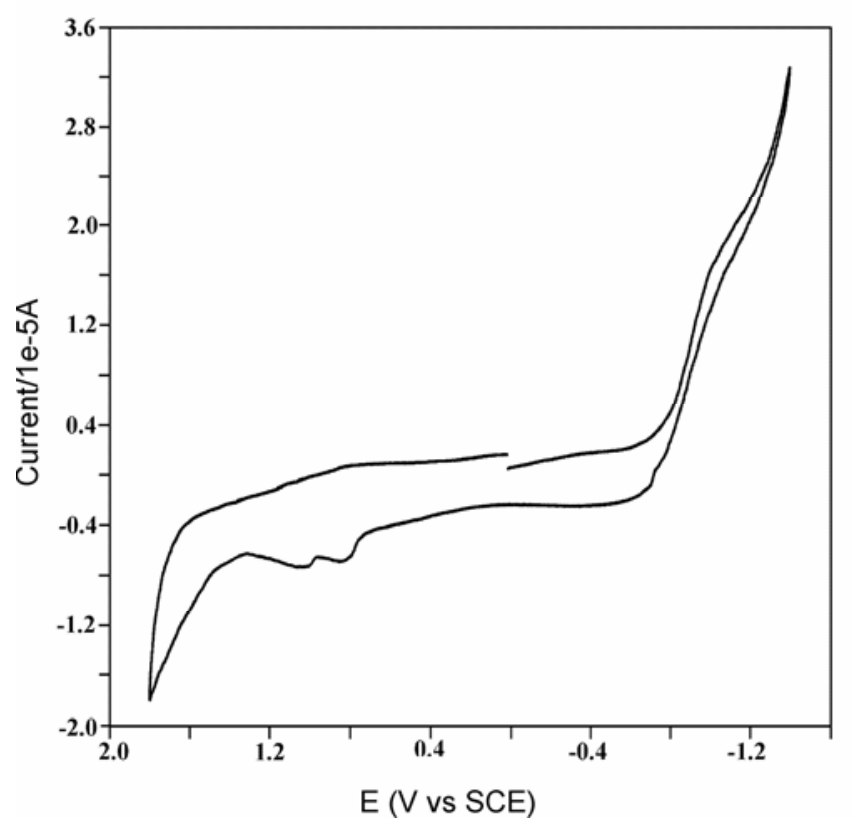

Figure 5. Cyclic voltammogram of $\left[\mathrm{Rh}\left(\mathrm{L}-\mathrm{OCH}_{3}\right)_{3}\right]$ complex in 1:9 dichloromethane-acetonitrile solution $\left(0 \cdot 1 \mathrm{M}\right.$ TBAP) at a scan rate of $50 \mathrm{mV} \mathrm{s}^{-1}$. whereby initial $\mathrm{N}-\mathrm{H}$ activation of a triazene ligand takes place generating a reactive hydride intermediate of rhodium. Further acid-base reactions between this hydride intermediate and two more triazene ligands finally affords the tris-triazenide complexes of rhodium(III). Interaction of these triazene ligands (1) with other reactive complexes of the platinum metals, expecting some interesting bond activation and/or bond cleavage reactions, are currently under exploration.

\section{Supplementary material}

Crystallographic data for the $\left[\mathrm{Rh}\left(\mathrm{L}-\mathrm{OCH}_{3}\right)_{3}\right]$ complexes in the CIF format have been deposited with the Cambridge Crystallographic Data Center, CCDC No. 698648.

\section{Acknowledgements}

The authors thank the reviewers for their critical comments and constructive suggestions, which have 
been of great help in preparing the revised manuscript. Financial assistance received from the UGCCAS Program of the Department of Chemistry, Jadavpur University, is gratefully acknowledged. M G B D thanks EPSRC (UK) and the University of Reading for funds for the Image Plate System. Chhandasi GuhaRoy thanks the University Grants Commission, New Delhi, for her fellowship [Grant No. 10-2(5)/2005(I)-E.U.II].

\section{References}

1. (a) Albertin G, Antoniutti S, Bedin M, Castro J and Garcia-Fontan S 2006 Inorg. Chem. 45 3816; (b) Creswell C J, Queiros M A M and Robinson S D 1982 Inorg. Chim. Acta 60 157; (c) Immirzi A, Porzio W, Bombieri G and Toniolo L $1980 \mathrm{~J}$. Chem. Soc., Dalton Trans. 1098; (d) Brown L D and Ibers J A 1976 J. Am. Chem. Soc. 981597

2. (a) Clark T, Cochrane, J, Colson S F, Malik K Z, Robinson S T and Steed J W 2001 Polyhedron 20 1875; (b) Pfeiffer D, Guzei I A, Liable-Sands L M, Heeg M J, Rheingold A L and Winter C H $1999 \mathrm{~J}$. Organomet. Chem. 588 167; (c) Westhusin S, Gantzel P and Walsh P 1998 J. Inorg. Chem. 37 5956; (d) Menon M, Pramanik A, Chattopadhyay S, Bag N and Chakravorty A 1995 Inorg. Chem. 34 1361; (e) Leman J T, Braddock-Wilking J, Coolong A J and Barron A R 1993 Inorg. Chem. 32 4324; (f) Colson S F and Robinson S D 1990 Polyhedron 9 1737; (g) Carriedo C, Connelly N G, Hettrich R, Orpen A G and White A M J $1989 \mathrm{~J}$. Chem. Soc., Dalton Trans. 745; (h) Hillhouse G L and Haymore B L 1987 Inorg. Chem. 26 1876; (i) Queiros M A M, Simao J E J and Dias A R 1987 J. Organomet. Chem. 32985

3. (a) Nuricumbo-Escobar J J, Campos-Alvarado C, Rios-Moreno G, Morales-Morales D, Walsh P J and Parra-Hake M 2007 Inorg. Chem. 46 6182; (b) Adams C J, Baber R A, Connelly N O, Hardeng P, Hayward O D, Kandiah M and Orpen A G 2007 J. Chem. Soc., Dalton Trans. 13 1325; (c) Tejel C, Ciriano M A, Rios-Moreno G, Dobrinovitch I T, Lahoz F J, Oro L A and Parra-Hake M 2004 Inorg. Chem. 43 4719; (d) Connelly N G, Hayward O D, Klangsinsirikul P and Orpen A G 2002 J. Chem. Soc., Dalton Trans. 305; (e) Ruiz J, Lopez G F J, Rodriguez V, Perez J, Ramirez de Arellano M C and Lopez G $2001 \mathrm{~J}$. Chem. Soc., Dalton Trans. 2683; (f) Gantzel P and Walsh P J 1998 Inorg. Chem. 373450 (g) Ang H G, Koh L L and Yang G Y 1996 J. Chem. Soc., Dalton Trans. 8 1573; (h) Connelly N G, Einig T, Garcia G, Herbosa G, Hopkins P M, Mealli C, Orpen A G, Rosair G M and Viguri F 1994 J. Chem. Soc., Dalton Trans. 2025; (i) Hursthouse M B, Mazid M A, Clark $\mathrm{T}$ and Robinson D 1993 Polyhedron 12 563; (j) Connelly N G and Garcia G 1987 J. Chem. Soc., Dalton Trans. 2737
4. (a) Smith M B K, Taneyhill L A, Michejda C J and Smith (Jr) R H 1996 Chem. Res. Toxicol. 9 341; (b) McConnaughie A M and Jenkins T C 1995 J. Med. Chem. 38 3488; (c) Smith(Jr) R H, Scudiero D A and Michejda C J $1990 \mathrm{~J}$. Med. Chem. 332579

5. GuhaRoy C, Butcher R J and Bhattacharya S $2008 \mathrm{~J}$. Organomet. Chem. 6933923

6. Evans D, Osborn J A and Wilkinson G 1968 Inorg. Synth. 1199

7. Hartman W W and Dickey J B 1943 Org. Synth. 2 163

8. (a) Sawyer D T and Roberts J L Jr 1974 Experimental electrochemistry for chemists (New York: Wiley) pp 167-215; (b) Walter M and Ramaley L 1973 Anal. Chem. 45165

9. The reaction does not occur in the absence of base $\left(\mathrm{NEt}_{3}\right)$.

10. Chemical shifts are given in ppm and multiplicity of the signals along with the associated coupling constants $(J$ in $\mathrm{Hz})$ are given in parentheses. Overlapping signals are marked with an asterisk

11. Sheldrick G M 1997 SHELXS-97 and SHELXL-97, Fortran programs for crystal structure solution and refinement, University of Gottingen: Gottingen, Germany

12. Laing K R, Robinson S D and Uttley M F $1974 J$. Chem. Soc., Dalton Trans. 1205

13. (a) Calhorda M. J 2000 Chem. Commun. 801; (b) Janiak C, Temizdemir S and Dechert S 2000 Inorg. Chem. Commun. 3 271; (c) Janiak C, Temizdemir S, Dechert S, Deck W, Girgsdies F, Heinze J, Kolm M. J, Scarmann T G and Zipffel O M 2000 Eur. J. Inorg. Chem. 1229; (d) Desiraju G R and Steiner T 1999 The weak hydrogen bond (IUCr monograph on crystallography 9), Oxford Science Publ.; (e) Hannon M J, Painting C L and Alcock N W 1999 Chem. Commun. 2023; (f) Mcnelis B J, Nathan L C and Clark C J 1999 J. Chem. Soc., Dalton Trans. 1831; (g) Biradha K, Seward C and Zaworotko M J 1999 Angew. Chem., Int. Ed. 38 492; (h) Burley S K and Petsko G A $1998 A d v$. Protein Chem. 39 125; (i) Nishio M, Hirota M and Umezawa Y 1998 The CH--- $\pi$ interactions (Evidence, Nature and Consequences), (New York: Wiley-VCH); (j) Umezawa Y, Tsuboyama S, Honda K, Uzawa J and Nishio M 1998 Bull. Chem. Soc., Jpn. 71 1207; (k) Madhavi N N L, Katz A K, Carrell H L, Nangia A and Desiraju G R 1997 Chem. Commun. 1953; (1) Weiss H C, Blaser D, Boese R, Doughan B M and Haley M M 1997 Chem. Commun. 1703; (m) Burley S K and Petsko G A 1985 Science 22923

14. (a) CelenligilCetin R, Watson L A, Guo C, Foxman B M and Ozerov O V 2005 Organometallics 24 186; (b) Li T, Churlaud R, Lough A J, Abdur-Rashid K and Morris R H 2004 Organometallics 23 6239; (c) Yi C S, Yun S Y and Guzei I A 2004 Organometallics 23 5392

15. The complex $\left[\mathrm{Rh}\left(\mathrm{L}-\mathrm{NO}_{2}\right)_{3}\right]$ does not have any absorption in the visible region 
16. (a) Mealli C and Proserpio D M 1990 J. Chem. Educ. 67 399; (b) Mealli C and Proserpio D M 1994 CACAO Version 4.0, Firenze, Italy

17. In the $\left[\mathrm{Rh}\left(\mathrm{L}-\mathrm{NO}_{2}\right)_{3}\right]$ complex the LUMO has significant contributions from the $\mathrm{NO}_{2}$ fragment

18. The excitation wavelength is different for the $[\mathrm{Rh}(\mathrm{L}-$ $\left.\mathrm{NO}_{2}\right)_{3}$ ] complex

19. (a) Cook M J, Lewis A P, Thomson G S J, Glasper J L and Robbins D J 1984 J. Chem. Soc., Perkin Trans.
293; (b) Crosby G A and Elfring Jr W H 1976 J. Phys. Chem. 802206

20. A little dichloromethane was necessary to take the complex into solution. Addition of large excess of acetonitrile was necessary to record the redox responses in proper shape

21. For the $\left[\mathrm{Rh}\left(\mathrm{L}-\mathrm{NO}_{2}\right)_{3}\right]$ complexes only one oxidation have been observed, probably because the other oxidation occurs beyond the voltage window 